\title{
Respons Masyarakat Kota Surabaya ketika Mengakses Informasi tentang Obat dan Pengobatan dari Media Sosial
}

Fatihatul Alifiyah, Anila Impian Sukorini, Andi Hermansyah*

Fakultas Farmasi, Universitas Airlangga, Surabaya, Indonesia

*Corresponding author: andi-h@ff.unair.ac.id

Submitted: 25 November 2020

Accepted: 31 December 2020

Published: 09 April 2021

\begin{abstract}
Background: The increased use of social media offers potential for spreading information related to health, particularly about drug and medication. However, social media often reported presenting information with poor quality. Objective: This study aims to explore the response of public when accessing information about drug and medication on social media. Methods: This research was cross-sectional study with the data was descriptively analyzed. This research was conducted between April and May 2020 with respondents are general public in Surabaya who were over 17 years old and has social media. Results: Most respondents often obtained drug and medication information from social media (43.5\%). However, they didn't try to clarify the information to health practitioner (88.6\%) and didn't seek the truth about the information by themselves (84.4\%). Respondents preferred to trust and apply drug and medication information if they perceived that the information are from credible and reliable sources (48.1\%). Conclusion: The myriad of drug and medication information ciruclated on social media might have confused respondents to select the correct information. Therefore, pharmacists, as a drug expertist, have a great opportunity to provide correct drug information on social media.
\end{abstract}

Keywords: drug information, social media, general public

\begin{abstract}
Abstrak
Pendahuluan: Media sosial berpotensi sebagai ruang baru untuk penyebaran informasi kesehatan, seperti informasi mengenai obat dan pengobatan. Namun, media sosial kerap kali menampilkan menyajikan informasi dengan kualitas yang buruk. Tujuan: Penelitian ini bertujuan mengetahui respons masyarakat saat mengakses informasi tentang obat dan pengobatan dari media sosial. Metode: Penelitian ini merupakan penelitian deskriptif yang dilakukan secara cross-sectional. Pengambilan data dilakukan pada April-Mei 2020 dengan responden masyarakat Kota Surabaya yang berusia $>17$ tahun dan memiliki media sosial. Hasil: Mayoritas responden menyatakan "sering" mendapatkan informasi obat dan pengobatan dari media sosial $(43,5 \%)$, Namun, sebagian besar responden belum mengklarifikasikan informasi obat dan pengobatan yang diperoleh ke tenaga kesehatan $(88,6 \%)$ ataupun melakukan penelusuran lebih dalam secara mandiri mengenai kebenarannya $(84,4 \%)$. Responden menyatakan akan percaya dan menerapkan informasi yang mereka dapatkan dari media sosial, bila informasi tersebut berasal dari sumber yang kredibel dan reliabel (48,1\%). Kesimpulan: Melimpahnya informasi tentang obat dan pengobatan yang beredar di media sosial membuat masyarakat kebingungan dalam memilah informasi obat dan pengobatan yang benar. Apoteker, sebagai ahli di bidang obat, memiliki peluang besar untuk menjadi sumber dan rujukan klarifikasi informasi obat dan pengobatan di media sosial.
\end{abstract}

Kata kunci: informasi obat, media sosial, masyarakat Surabaya 


\section{PENDAHULUAN}

Berdasarkan survei oleh Hootsuite pada awal tahun 2019, jumlah pengguna media sosial secara global telah mencapai angka 54\% dari total populasi manusia (Hootsuite, 2019). Jumlah tersebut meningkat sebanyak 9\% dari tahun sebelumnya dan diperkirakan akan terus meningkat dalam beberapa tahun ke depan. Di Indonesia, pengguna media sosial hingga Januari tahun 2019 telah menyentuh angka 56\% dengan pengguna terbanyak pada rentang usia 18-34 tahun. Proses digitalisasi diatas memicu berbagai perubahan di berbagai sektor, tak terkecuali di bidang kesehatan (Asur \& Huberman, 2010).

Peningkatan penggunaan media sosial turut memunculkan potensi media sosial sebagai ruang baru untuk penyebaran informasi kesehatan seperti informasi mengenai obat dan pengobatan (Vance dkk., 2009; Cumbraos-Sánchez dkk., 2019). Hal ini disebabkan, media sosial menawarkan suatu kemudahan untuk berinteraksi dengan pasien secara cepat, efektif untuk membuat jadwal konsultasi dengan tenaga kesehatan, dan memfasilitasi adanya diskusi secara grup (Li dkk., 2016).

Berdasarkan sebuah survei, $40 \%$ dari pengguna media sosial yang mencari informasi kesehatan melalui media sosial juga membagikannya kepada pengguna lain (Duggan \& Fox, 2013). Sebuah penelitian di Belanda menyatakan pasien umumnya menggunakan Twitter $(59,9 \%)$ utamanya untuk menambah pengetahuan mengenai pengobatan dan bertukar saran pengobatan, dan Facebook (52,3\%) untuk saling memberi dukungan dan bertukar saran pengobatan (Antheunis dkk., 2013).

Namun adanya informasi kesehatan termasuk obat dan pengobatan di media sosial juga memiliki efek negatif. Media sosial dilaporkan memberikan informasi dengan kualitas yang diragukan, tidak memiliki sumber yang dapat dipertanggungjawabkan, dan menyesatkan (Lee Ventola, 2014)

Selain itu, sangat sulit untuk memantau akurasi dan kesahihan dari informasi pengobatan yang beredar di media sosial. Sebagai akibatnya, informasi yang salah dan menyesatkan dapat merugikan pasien dan bisa mempengaruhi kepercayaan pasien pada dokter (De Martino dkk., 2017).

Berdasarkan sebuah penelitian di Bahrain, 13 dari $22(59,1 \%)$ informasi mengenai pengobatan dan obat, yang terpantau selama satu tahun beredar di WhatsApp, berpotensi sebagai informasi yang menyesatkan. Informasi tersebut diantaranya melebih- lebihkan efek samping tanpa mempertimbangkan faktor-faktor lain, efek klinis yang dilebih-lebihkan, dan penggunaan bukti klinis yang kurang terpercaya untuk meningkatkan klaim terhadap obat tertentu (Al Khaja dkk., 2018).

Penelitian ini dilakukan di Kota Surabaya mengingat Surabaya memiliki tingkat penetrasi internet cukup tinggi yakni $60 \%$ dan menjadikannya dalam jajaran 5 besar daerah dengan penetrasi internet tertinggi di Indonesia, sehingga masyarakat telah terbiasa terpapar media sosial (APJII, 2019). Oleh karena itu, penting untuk dilakukan penelitian yang bertujuan mengetahui respon masyarakat Kota Surabaya ketika mengakses informasi obat dan pengobatan dari media sosial.

\section{BAHAN DAN METODE Desain penelitian}

Penelitian ini merupakan penelitian kuantitatif dengan pendekatan deskriptif yang dilakukan secara cross-sectional. Penelitian ini telah mendapat Surat Laik Etik dari Komisi Etik Penelitian Kesehatan Fakultas Farmasi Universitas Airlangga nomor 10/LE/2020.

\section{Tempat dan waktu penelitian}

Penelitian dilakukan sejak Agustus 2019 hingga Mei 2020, dimulai dari identifikasi masalah hingga penyusunan naskah. Untuk pengambilan data dilakukan pada bulan April - Mei 2020 dengan cara menyebarkan kuisioner via Survey Monkey.

\section{Populasi dan sampel penelitian}

Populasi dari penelitian ini adalah masyarakat Kota Surabaya pengguna media sosial. Sedangkan, Sampel dalam penelitian ini adalah masyarakat Kota Surabaya yang memenuhi kriteria inklusi. Berdasarkan perhitungan jumlah sampel dengan populasi tak terbatas (Ogston dkk., 1991), diperoleh jumlah sampel minimal yang dibutuhkan dalam penelitian ini adalah 261 responden.

Kriteria inklusi sampel penelitian ini ialah penduduk Kota Surabaya, yakni orang yang berdomisili di wilayah Surabaya; dengan usia 17 tahun keatas; menggunakan gawai serta memiliki media sosial atas nama pribadi; dan bersedia menjadi responden penelitian. Kriteria eksklusi pada penelitian ini adalah responden yang mengundurkan diri, tidak menyelesaikan kuisioner atau responden yang menyatakan tidak pernah mendapat informasi obat dan pengobatan dari media sosial. 


\section{Variabel penelitian}

Menurut Sugiyono (2016), variabel penelitian adalah segala sesuatu yang berbentuk apa saja yang ditetapkan oleh peneliti untuk dipelajari sehingga diperoleh informasi tentang hal tersebut. Pada penelitian ini, variabel dikembangkan berdasarkan teori Difussion of innovation yang dikembangkan oleh Rogers (1997), yaitu sebagai berikut:

1. Karakteristik pengadopsi (Karakteristik sosioekonomi)

2. Tahapan Adopsi (knowledge, persuasion, decision, implementation, confirmation)

\section{Teknik dan instrumen pengambilan data}

Responden dipilih berdasarkan teknik accidental sampling. Responden diperoleh melalui undangan untuk pengisian kuisioner yang disebar oleh peneliti di berbagai situs media sosial. Penelitian ini menggunakan kuesioner self-administered, dimana kuesioner diisi sendiri oleh responden setelah menyatakan setuju pada pertanyaan yang memuat informed consent.

\section{Teknik analisis data}

Perolehan data dari kuesioner ditabulasi dan selanjutnya disajikan secara deskriptif dalam bentuk persentase (\%) dan frekuensi (n).

\section{HASIL DAN PEMBAHASAN}

Penelitian ini diikuti oleh 262 responden, mayoritas adalah perempuan (77\%), usia mayoritas responden adalah 21 - 30 tahun (59\%), sebagian besar telah menamatkan pendidikan tinggi (54\%), menggunakan media sosial selama 6 - 10 tahun terakhir (52\%) dengan WhatsApp menjadi aplikasi media sosial yang dimiliki oleh semua responden.

Dengan pesatnya peningkatan jumlah pengguna media sosial, memunculkan media sosial sebagai ruang baru untuk penyebaran berbagai informasi. Bahkan, di saat terjadi wabah seperti saat proses pengambilan data penelitian, muncul fenomena baru yakni terjadinya ledakan informasi kesehatan di media sosial, termasuk mengenai obat dan pengobatan (Pulido dkk., 2020). Pernyataan ini sesuai dengan hasil penelitian yang mana seluruh responden kerap memperoleh informasi obat dan pengobatan dari media sosial. Tabel 1 berikut merupakan data demografi responded.

Tabel 1. Data demografi responden $(n=262)$

\begin{tabular}{|c|c|c|}
\hline Demografi & & \\
\hline \multirow[t]{2}{*}{ Jenis Kelamin } & Laki-laki & $60 \quad(22,9 \%)$ \\
\hline & Perempuan & $202(77,1 \%)$ \\
\hline \multirow[t]{6}{*}{ Usia } & $\leq 20$ tahun & $26(9,9 \%)$ \\
\hline & $21-30$ tahun & $154(58,8 \%)$ \\
\hline & $31-40$ tahun & $35 \quad(13,4 \%)$ \\
\hline & $41-50$ tahun & $39(14,9 \%)$ \\
\hline & $51-60$ tahun & $7 \quad(2,7 \%)$ \\
\hline & $>60$ tahun & $1 \quad(0,3 \%)$ \\
\hline \multirow[t]{5}{*}{ Riwayat pendidikan terakhir } & SMP & $1 \quad(0,4 \%)$ \\
\hline & SMA & $101(38,5 \%)$ \\
\hline & Diploma & $18(6,9 \%)$ \\
\hline & Sarjana/ Master/ Doktor & $142(54,2 \%)$ \\
\hline & $<1$ tahun & $1 \quad(0,4 \%)$ \\
\hline \multirow[t]{3}{*}{ Lama menggunakan Media Sosial } & $1-5$ tahun & $35(13,4 \%)$ \\
\hline & $6-10$ tahun & $137(52,3 \%)$ \\
\hline & $>10$ tahun & $89(34,0 \%)$ \\
\hline \multirow[t]{2}{*}{ Media sosial yang digunakan } & WhatsApp & $262(100 \%)$ \\
\hline & Instagram & $230(87,8 \%)$ \\
\hline \multirow{6}{*}{$\begin{array}{l}\text { *) responden boleh menjawab lebih } \\
\text { dari } 1\end{array}$} & Facebook & $181(69,1 \%)$ \\
\hline & Line & $171(65,3 \%)$ \\
\hline & YouTube & $171(65,3 \%)$ \\
\hline & Twitter & $131(50,0 \%)$ \\
\hline & Telegram & $88(33,6 \%)$ \\
\hline & Blog & $30(11,4 \%)$ \\
\hline
\end{tabular}

Tabel 2. Bentuk respon atas pengaksesan informasi obat dan pengobatan dari media sosial $(\mathrm{n}=262)$ 
Jurnal Farmasi Dan Ilmu Kefarmasian Indonesia

Special Issue: Seminar Inovasi Teknologi dan Digitalisasi Pada Pelayanan Kefarmasian 2020

\begin{tabular}{|c|c|c|c|c|c|c|}
\hline \multirow[t]{2}{*}{ No. } & \multirow[t]{2}{*}{ Pernyataan } & $\begin{array}{l}\text { Tidak } \\
\text { Pernah }\end{array}$ & Jarang & $\begin{array}{l}\text { Kadang- } \\
\text { kadang }\end{array}$ & Sering & Selalu \\
\hline & & $\mathrm{n}(\%)$ & $\mathrm{n}(\%)$ & $\mathrm{n}(\%)$ & $\mathrm{n}(\%)$ & $\mathrm{n}(\%)$ \\
\hline 1. & $\begin{array}{l}\text { Saya pernah mendapatkan atau menemukan informasi } \\
\text { obat dan pengobatan dari media sosial }\end{array}$ & $\begin{array}{c}0 \\
(0,0)\end{array}$ & $\begin{array}{c}30 \\
(11,5)\end{array}$ & $\begin{array}{c}113 \\
(43,1)\end{array}$ & $\begin{array}{c}114 \\
(43,5)\end{array}$ & $\begin{array}{c}5 \\
(1,9)\end{array}$ \\
\hline 2. & $\begin{array}{l}\text { Saat saya mendapatkan informasi obat dan pengobatan } \\
\text { dari media sosial saya akan mengklarifikasikan } \\
\text { informasi tersebut ke tenaga kesehatan }\end{array}$ & $\begin{array}{c}43 \\
(16,4)\end{array}$ & $\begin{array}{c}68 \\
(26,0)\end{array}$ & $\begin{array}{c}76 \\
(29,0)\end{array}$ & $\begin{array}{c}45 \\
(17,2)\end{array}$ & $\begin{array}{c}30 \\
(11,4)\end{array}$ \\
\hline 3. & $\begin{array}{l}\text { Saya melakukan penelusuran/mempelajari lebih dalam } \\
\text { tentang kebenaran informasi obat dan } \\
\text { pengobatan dari media sosial }\end{array}$ & $\begin{array}{c}56 \\
(21,4)\end{array}$ & $\begin{array}{c}41 \\
(15,6)\end{array}$ & $\begin{array}{c}84 \\
(32,2)\end{array}$ & $\begin{array}{c}79 \\
(30,2)\end{array}$ & $\begin{array}{c}41 \\
(15,6)\end{array}$ \\
\hline 4. & $\begin{array}{l}\text { Saya mempercayai informasi obat dan pengobatan yang } \\
\text { saya dapatkan dari media sosial }\end{array}$ & $\begin{array}{c}16 \\
(6,1)\end{array}$ & $\begin{array}{c}78 \\
(29,8)\end{array}$ & $\begin{array}{c}136 \\
(51,9)\end{array}$ & $\begin{array}{c}31 \\
(11,8)\end{array}$ & $\begin{array}{c}1 \\
(0,4)\end{array}$ \\
\hline 5. & $\begin{array}{l}\text { Saya menerapkan informasi obat dan pengobatan dari } \\
\text { media sosia }\end{array}$ & $\begin{array}{c}29 \\
(11,1)\end{array}$ & $\begin{array}{c}90 \\
(34,4)\end{array}$ & $\begin{array}{c}113 \\
(43,1)\end{array}$ & $\begin{array}{c}30 \\
(11,4)\end{array}$ & $\begin{array}{c}0 \\
(0,0)\end{array}$ \\
\hline 6. & $\begin{array}{l}\text { Saya mendapat hasil sesuai dengan yang saya inginkan } \\
\text { dari penerapan informasi obat dan pengobatan } \\
\text { dari media sosial }\end{array}$ & $\begin{array}{c}31 \\
(11,8)\end{array}$ & $\begin{array}{c}60 \\
(22,9)\end{array}$ & $\begin{array}{c}121 \\
(46,2)\end{array}$ & $\begin{array}{c}46 \\
(17,6)\end{array}$ & $\begin{array}{c}4 \\
(1,5)\end{array}$ \\
\hline 7. & $\begin{array}{l}\text { Saya membagikan/mempromosikan informasi obat dan } \\
\text { pengobatan yang saya terapkan dari media } \\
\text { sosial kepada orang lain }\end{array}$ & $\begin{array}{c}77 \\
(29,4)\end{array}$ & $\begin{array}{c}96 \\
(36,6)\end{array}$ & $\begin{array}{c}68 \\
(26,0)\end{array}$ & $\begin{array}{c}20 \\
(7,6)\end{array}$ & $\begin{array}{c}1 \\
(0,4)\end{array}$ \\
\hline
\end{tabular}

Pada Tabel 2 dapat dilihat bahwa mayoritas repsponden selalu menerima informasi obat dan pengobatan khususnya dari media sosial. Dengan didapatkannya informasi obat dari media sosial, yang mana dapat dikategorikan sebagai inovasi, yaitu sebuah ide baru yang didapat oleh individu, Rogers (1997) menjelaskan bahwa akan terjadi proses adopsi sebagai suatu respon. Respon tersebut terbagi menjadi lima tahap seperti yang digambarkan pada Tabel 2, yaitu knowledge (pernyataan 1), persuasion (pernyataan 2 dan 3), decision (pernyataan 4), implementation (pernyataan 5), dan confirmation (pernyataan 6 dan 7).

Respon masyarakat dimulai dengan tahap "knowledge" yang diwakili, yakni ketika masyarakat mulai mengenal adanya inovasi. Dalam penelitian ini, tahapan ini dedifinisikan sebagai proses masyarakat mulai mengenali atau mengetahui adanya informasi obat dan pengobatan dari media sosial. Mayoritas responden (43,5\%) menyatakan "sering" mendapatkan informasi obat dan pengobatan dari media sosial (Tabel 2).

Dalam proses "knowledge", Rogers menjelaskan bahwa salah satu faktor yang berperan ialah karakteristik sosio-ekonomi. Kelompok usia remaja/dewasa muda adalah pengadopsi media sosial tercepat bila dibandingkan dengan kelompok usia dewasa tua, walaupun saat ini jumlah kelompok usia dewasa tua yang menggunakan media sosial juga terus bertambah (Pew Research Center, 2019). Hal ini sesuai dengan data penelitian yang menyatakan bahwa mayoritas responden berusia 21 - 30 tahun. Akibatnya, di masa mendatang internet dan media sosial berperan besar dalam dunia kesehatan, tidak hanya dalam penyebaran informasi tetapi juga sistem kesehatan itu sendiri.

Mayoritas responden yang menerima informasi obat dan pengobatan adalah perempuan $(77 \%$ ) (Tabel 1). Pernyataan ini didukung penelitian lain yang juga mengungkapkan bahwa, perempuan lebih menggunakan media sosial untuk mendapatkan informasi dan mencari pengalaman dibandingkan pria (Alnjadat dkk., 2019).

Selain itu, diketahui bahwa mayoritas responden telah menggunakan media sosial selama 6-10 tahun (Tabel 1). Berdasarkan penelitian oleh Yu dkk. (2017), semakin seseorang berpengalaman dengan media TIK semakin tinggi adopsi informasi dari media TIK tersebut. Selain itu, mayoritas responden berpendidikan tinggi (Tabel 1), hal ini dapat dikarenakan penetrasi penggunaan internet pada tamatan pendidikan tinggi lebih tinggi dibanding level pendidikan dibawahnya (APJII, 2019).

Untuk memberikan sikap atau penilaian (tahap persuasion) dapat juga dibantu oleh pihak lain, misal melakukan klarifikasi ke pihak lain seperti tenaga kesehatan. Namun, mayoritas responden memilih "kadang-kadang" (29\%) dan "jarang" (26\%) dalam hal mengklarifikasikan informasi obat dan pengobatan ke tenaga kesehatan, Selain itu, mayoritas responden $(32,1 \%)$ menyatakan masih terkadang melakukan penelusuran mandiri mengenai kebenaran informasi yang mereka dapatkan (Tabel 2). 
Data ini serupa dengan penelitian di London, bahwa 47,3\% responden tidak mengkonsultasikan informasi kesehatan yang diterima ke tenaga kesehatan (Crilly dkk., 2019). Data diatas menunjukkan, masyarakat belum terlalu aktif untuk mengklarifikasikan informasi yang didapatkan. Apoteker sebagai salah satu praktisi obat dapat menjadikan hal ini sebagai suatu kesempatan untuk melakukan tanggung jawab profesi sebagai ahli dibidang obat. Penelitian di Pulau Jawa, memperlihatkan bahwa sudah ada peran apoteker sebagai rujukan pertama dalam mengklarifikasi informasi obat dan pengobatan (Hermansyah dkk., 2019).

Penelitian di London mengungkapkan bahwa masyarakat London lebih mempercayai aplikasi kesehatan dibandingan media sosial dalam memuat informasi, hal ini dikarenakan aplikasi kesehatan dikelola oleh badan resmi tertentu (Crilly dkk., 2019).Hal ini menunjukkan bahwa besarnya potensi penggunaan aplikasi kesehatan di masa mendatang sebagai bagian dari sistem kesehatan.

Setelah calon pengadopsi memberi penilaian maka tahapan selanjutnya ialah tahap decision atau tahap keputusan, yang mana calon pengadopsi dapat menerima atau menolak untuk menerapkan informasi obat dan pengobatan yang mereka terima dari media sosial. 51,9\% responden menyatakan "kadang-kadang" dan $29,8 \%$ "jarang" mempercayai informasi obat dan pengobatan dari media sosial (Tabel 2). Hal ini dijelaskan oleh Crilly dkk. (2019) bahwa media sosial memiliki isu mengenai tingkat kepercayaan, dikarenakan tidak adanya pengawasan dengan konten di media sosial yang membuat publik sulit membedakan informasi yang benar dan salah.

Selain itu, media sosial memungkinkan siapa saja untuk menulis informasi mengenai obat dan pengobatan. Hal ini menjadi tantangan tersendiri mengingat aspek validitas dari informasi yang dibagikan menjadi semakin meragukan (Gutierrez dkk., 2017). Hal tersebut menurut Rogers akan menimbulkan aspek ketidakpastian (uncertainty) untuk diterapkan. Masyarakat akan mengadopsi suatu inovasi jika mereka merasa percaya bahwa inovasi tersebut akan memenuhi kebutuhan mereka. Oleh karena itu, mereka harus percaya bahwa inovasi tersebut akan memberikan keuntungan relatif lebih besar dibanding aspek ketidakpastian yang ditimbulkan.

Untuk memutuskan keterpercayaan (tahap decision) sebuah informasi obat dan pengobatan dari media sosial serta untuk menghilangkan aspek ketidakpastian, mayoritas responden mengacu pada siapa yang mengirimkan dan bagaimana kredibilitas dari informasi misalkan adanya testimoni, adanya klarifikasi ahli, pustaka ilmiah, dan hasil penelusuran pribadi (Tabel 3). Dengan terpilihnya sumber informasi menjadi faktor nomor satu yang menentukan tingkat kepercayaan, hal ini menjadi kekuatan tersendiri bagi seorang apoteker bila membagikan sumber informasi berkaitan dengan obat dan pengobatan. Untuk itu, perlu dilakukan penelitian lebih lanjut untuk melihat sejauh mana apoteker berperan sebagai influencer dan bagaimana penerimaan dari masyarakat.

Tabel 3. Faktor keterpercayaan terhadap informasi obat dan pengobatan di media sosial $(\mathrm{n}=262)$

\begin{tabular}{llc}
\hline Faktor & & $\mathrm{n}(\%)$ \\
\hline Sumber informasi & Pengirim/sumber informasi yang kredibel & $126(48,1 \%)$ \\
\hline Kredibilitas & Terdapat testimoni dari orang yang sudah mencoba & $31(11,8 \%)$ \\
informasi & Telah dibenarkan oleh tenaga kesehatan/ ahli & $23(8,8 \%)$ \\
& Terdapat pustaka ilmiah & $25(9,5 \%)$ \\
& Hasil dari penelusuran kebenaran informasi secara & $10(3,8 \%)$ \\
& pribadi & $14(5,3 \%)$ \\
\hline Konten informasi & Logis atau relevan & $11(4,2 \%)$ \\
& Konten yang detail dan menarik & $10(3,8 \%)$ \\
& Pengobatan dari bahan alam/ tradisional & $8(3,1 \%)$ \\
\hline Kebutuhan & Informasi sering diperoleh & $12(4,6 \%)$ \\
\hline Tidak menjawab & Sesuai dengan kebutuhan atau keyakinan & $11(4,2 \%)$ \\
\hline *) responden boleh & menjawab lebih dari 1
\end{tabular}

Pada tahap implementation, $43,1 \%$ responden menyatakan "kadang-kadang" dan 34,4\% menyatakan "jarang", bahkan 11,1\% menyatakan "tidak pernah" menerapkan informasi obat dan pengobatan dari media sosial (Tabel 2). Data ini menunjukkan bahwa penerapan informasi obat dan pengobatan masih 
rendah. Hal ini dapat dikarenakan adanya aspek "uncertainty" dan isu terkait keterpercayaan dalam informasi yang ditawarkan.

Mayoritas responden $(36,6 \%)$ menyatakan jarang membagikan informasi obat dan pengobatan ke pengguna lain di media sosial, bahkan 29,4\% menyatakan tidak pernah dan hanya 1 responden $(0,4 \%)$ yang menyatakan selalu mengirimkan informasi obat dan pengobatan dari media sosial (Tabel 2). Data ini menunjukkan bahwa ada rasa waspada dalam responden bila berkaitan dengan penyebaran informasi obat dan pengobatan dari media sosial, mengingat banyaknya misinformasi yang beredar di media sosial.

Bahkan, dikarenakan maraknya misinformasi di Indonesia seorang peneliti Amerika melakukan penelitian mengenai penyebaran misinformasi di Indonesia. Dari penelitian itu diketahui bahwa karakteristik responden mempengaruhi perilaku penyebaran misinformasi, salah satunya semakin rendah tingkat pendidikan dan periode penggunaan media sosial semakin sering terjadinya penyebaran informasi tanpa verifikasi kebenaran informasi tersebut (Khan \& Idris, 2019).

Implikasi dari hasil penelitian ini, peneliti merekomendasikan untuk apoteker turut mengambil peran menjadi sumber informasi obat dan pengobatan, baik skala kecil maupun skala besar. Walaupun, pemberian informasi obat dan pengobatan di media sosial belum menjadi suatu keharusan dari pelayanan kefarmasian yang diatur oleh perundang-undangan. Namun, dengan adanya sosok apoteker di media sosial dapat meningkatkan eksistensi dan rasa keterpercayaan masyarakat dengan profesi apoteker. Media sosial menjadi media yang efektif untuk edukasi apalagi untuk kelompok usia muda, mengingat tingginya penggunaan media sosial di kelompok usia tersebut. Apoteker dapat menjadikan media sosial tidak hanya sebagai penggunaan pribadi, namun juga menjadikan media sosialnya untuk ranah profesi, semisal membuka akun profesional dimana masyarakat dapat mengakses untuk mencari ataupun mengklarifikasikan informasi obat dan pengobatan di media sosial.

Selain itu, masyarakat menaruh perhatian besar pada sumber pengirim informasi, dan menjadikan tenaga kesehatan sebagai rujukan informasi obat dan pengobatan dari media sosial, hal ini menjadi kesempatan besar bagi apoteker untuk meningkatkan eksistensi profesi di masyarakat. Untuk pengemasan informasi, masyarakat cenderung menyukai informasi yang dikemas secara menarik, menggunakan bahasa yang mudah dipahami, detail, dan adanya referensi yang jelas. Proses adopsi juga lebih tinggi pada informasi-informasi obat dan pengobatan yang dimuat oleh YouTube dan Blog, dikarenakan adanya pertemuan antara kebutuhan dan informasi yang disajikan. Sehingga, dapat disarankan apoteker untuk memilih kedua platform media sosial tersebut dalam melakukan penyebaran informasi obat dan pengobatan.

\section{KESIMPULAN}

Walaupun informasi tentang obat dan pengobatan telah sering didapat dari media sosial, namun masyarakat masih belum dapat memilah informasi obat dan pengobatan yang benar. Apoteker sebagai ahli di bidang obat, memiliki peluang besar untuk menjadi sumber dan rujukan klarifikasi informasi obat dan pengobatan di media sosial.

\section{UCAPAN TERIMA KASIH}

Artikel ini telah dipaparkan pada kegiatan seminar nasional dan temu ilmiah di Fakultas Farmasi Universitas Airlangga tanggal 26 September 2020.

\section{DAFTAR PUSTAKA}

Alnjadat, R,Hmaidi, M. M., Samha, T. E., Kilania, M. M. \& Hasswan, A. M. (2019). Gender Variations in Social Media Usage and Academic Performance Among the Students of University of Sharjah. Journal of Taibah University Medical Sciences; 14; 390-394.

Antheunis, M. L., Tates, K. \& Nieboer, T. E. (2013). Patients' and Health Professionals' Use of Social Media In Health Care: Motives, Barriers and Expectations. Patient Education and Counseling; 92; 426-431.

Asosiasi Penyelenggara Jasa Internet Indonesia (APJII). (2019). Penetrasi \& Profil Perilaku Pengguna Internet Indonesia. Jakarta: APJII.

Asur, S. \& Huberman, B. A. (2010). Predicting the Future With Social Media. IEEE/WIC/ACM International Conference on Web Intelligence; WI 2010; 492-499.

Crilly, P., Jair, S., Mahmood, Z., Moin Khan, A., Munir, A., Osei-Bediako, I. \& Kayyali, R. (2019). Public Views of Different Sources of Health Advice: Pharmacists, Social Media and Mobile Health Applications. International Journal of Pharmacy Practice; 27; 88-95.

Cumbraos-Sánchez, M. J., Hermoso, R., Iñiguez, D., Paño-Pardo, J. R., Allende Bandres, M. Á. \& 
Jurnal Farmasi Dan Ilmu Kefarmasian Indonesia

Special Issue: Seminar Inovasi Teknologi dan Digitalisasi Pada Pelayanan Kefarmasian 2020

Latorre Martinez, M. P. (2019). Qualitative and Quantitative Evaluation of the Use of Twitter As a Tool of Antimicrobial Stewardship. International Journal of Medical Informatics; $131 ; 103955$.

De Martino, I., D’Apolito, R., McLawhorn, A. S., Fehring, K. A., Sculco, P. K. \& Gasparini, G. (2017). Social Media for Patients: Benefits and Drawbacks. Current Reviews in Musculoskeletal Medicine;10; 141-145.

Duggan, M. \& Fox, S. (2013). PEW Internet Health Online 2013. Washington, D.C: Pew Research Center.

Gutierrez, M. A., Moreno, R. A. \& Rebelo, M. S. (2017). Information and Communication Technologies and Global Health Challenges, Global Health Informatics: How Information Technology Can Change Our Lives in a Globalized World. Cambridge: Academic Press.

Hermansyah, A., Sukorini, A. I., Asmani, F., Suwito, K. A. \& Rahayu, T. P. (2019). The Contemporary Role and Potential of Pharmacist Contribution for Community Health Using Social Media. Journal of Basic and Clinical Physiology and Pharmacology; 2019; 1-8.

Hootsuite. (2019). The Global State of Digital in 2019 report by Hootsuite. https://hootsuite.com/pages/digital-in-2019 (Accessed 12 December 2019).

Al Khaja, K. A. J., Al Khaja, A. K. \& Sequeira, R. P. (2018). Drug Information, Misinformation, and Disinformation on Social Media: a Content Analysis Study. Journal of Public Health Policy; 39; 343-357.

Khan, M. L. \& Idris, I. K. (2019). Recognise Misinformation and Verify Before Sharing: a Reasoned Action and Information Literacy Perspective. Behaviour and Information
Technology; 38; 1194-1212.

Lee Ventola, C. (2014). Social Media and Health Care Professionals: Benefits, Risks, and Best Practices. Pharmacy and Therapeutics; 39; 491-500.

Li, Y., Wang, X., Lin, X. \& Hajli, M. (2016). Seeking and Sharing Health Information on Social Media: a Net Valence Model and Cross-Cultural Comparison. Technological Forecasting \& Social Change; 126; 28-40.

Ogston, S., Lemeshow, S., Hosmer, D., Klar, J. \& Lwanga, S. (1991). Adequacy of Sample Size in Health Studies. Biometrics; 47; 347.

Pew Research Center. (2019). Social Media Use Over Time by Pew Research Center. http://www.pewinternet.org/data-trend/socialmedia/social-media-use-all-users/ (Accessed: 17 December 2019).

Pulido, C. M., Ruiz-Eugenio, L., Redondo-Sama, G. \& Villarejo-Carballido, B. (2020). A New Application of Social Impact in Social Media for Overcoming Fake News in Health. International Journal of Environmental Research and Public Health; 17; 2430.

Sugiyono. (2016). Metode Penelitian Kuantitatif, Kualitiatif, dan R\&D. Bandung: CV Alfabeta.

Rogers, E. M. (1997). Diffusion of Innovations, third edit. New York: The Free Press.

Vance, K., Howe, W. \& Dellavalle, R. P. (2009). Social Internet Sites as a Source of Public Health Information. Dermatologic Clinics; 27; 133-136.

Yu, T. K., Lin, M. L. \& Liao, Y. K. (2017). Understanding Factors Influencing Information Communication Technology Adoption Behavior: the Moderators of Information Literacy and Digital Skills. Computers in Human Behavior; 71; 196-208. 